\title{
Upstream with a shovel or downstream with a water right? Irrigation in a changing climate
}

\author{
Kelsey C. Cody ${ }^{1}$ \\ ${ }^{1}$ Environmental Studies Program, University of Colorado, Boulder, 397 UCB University of \\ Colorado, Boulder, CO 80309, USA, codykc@colorado.edu
}

\begin{abstract}
Irrigation of crops is responsible for 40 percent of the world's food supply. A ubiquitous issue in irrigation is the tendency of upstream users to deplete the stream and deprive downstream users of water. Climate change threatens to exacerbate this problem by threatening the water supply to many irrigation systems, especially those that rely on snowmelt. Using a natural experiment in the Rio Grande Basin of Colorado, I examine five hypotheses about how water rights and physical properties of irrigation systems interact to produce varying levels of irrigation performance. Results indicate that enforced water rights are reliably influential, but their influence depends on diversion location, geographic features of the watershed, physical water availability, and higher level water policy. Results highlight the interdependence of institutions and geography and support a role for carefully crafted water rights congruent with cultural norms and higher level policy in adaptation to climate change.
\end{abstract}

Key Words: Climate Change; Adaptation; Irrigation; Water Rights; Norms; Prior Appropriation

\section{Highlights:}

1) Water rights and geographic features are investigated and compared

2) The influence of water rights on irrigation is strong

3) The influence of water rights on irrigation varies depending on geography

4) Drought can increase water rights' influence on irrigation

5) Water rights may be moderated by norms and higher level policy

Acknowledgements: This study would not have been possible without NSF grant BCS1115009. Human Subjects Research approved with CU IRB Protocol Number: 13-0181. The author thanks Krister Andersson, Steven Smith, Alan Zarychta, Lisa Dilling, Michael Cox, Matthew Foster, Doug Kenney, and Tanya Heikkila for their advice in shaping this document and their assistance with data collection and analysis. The author also thanks the farmers and water managers in the SLV for their hospitality, advice, and - most importantly - time. The responsibility for all content and any remaining errors rest solely with the author. 


\section{Introduction}

\subsection{Study Summary}

One of the major challenges facing water management around the globe is the interaction between upstream and downstream water users. In theory, water rights should be an effective way to mitigate the "stationary bandit" behavior of upstream users (Janssen et al., 2011). But are they in practice? And to what degree does climate change influence upstream-downstream relationships when water rights are involved? To address these questions, this study looks at irrigation performance in the Rio Grande Basin in Colorado, commonly referred to as the San Luis Valley (SLV), where snowmelt dependent irrigation is the dominant economic activity. Like other regions of the world, the SLV hosts informally and formally enforced water rights, multiple watersheds with differing physical, cultural, and policy environments, and hundreds of irrigation systems with a wide range of attributes. Importantly, the SLV has ample public data on geography, hydrology, climate, and irrigation systems, offering a chance to control for effects that might be difficult to engage elsewhere.

At a minimum, an irrigation system is defined as the physical infrastructure used to capture, divert, and deliver water to the fields of irrigated farmers (Ostrom, 1992). In studies of irrigation systems, the users of the system as well as the lands irrigated by the system are also covered by the phrase "irrigation system" (Ostrom, 1992; Lam, 1998, Cox \& Ross, 2011). To say that these irrigation systems are user-governed means that farmers themselves maintain and manage the distribution of water through the headgates, canals, and ditches (Mabry, 1996). Irrigation performance in this study is measured at the level of the irrigation system (not individual farmers), and is assessed by three metrics for each year of the study period (1984-2015): the percentage of irrigable land irrigated by a given system, the percentage of the maximum volume of water diverted by a given system over the study period, and the number of calendar months over the calendar year during which water was diverted by a given system. See Section 2.1 of the supplementary material for more information on irrigation performance.

Irrigation performance is important for global food security, a growing problem that will be made worse as the climate changes and demands on water resources grow (Castex, et al., 2015; Cox, 2014; Fernald et al., 2012; Hurlbert \& Mussetta, 2016; Wheeler \& von Braun, 2013). Irrigation of crops is responsible for 40 percent of the world's food supply and is expected to provide most new food (UN IFAD, n.d.). Climate change threatens the water supply to many irrigation systems (FAO, 2012; Gleick, 2003), and therefore global food security. Because approximately three quarters of irrigated cropland and one quarter of all cropland relies on smallscale, user-governed irrigation systems worldwide (Mabry, 1996), adaptation will be performed primarily by farmers. In this context, user-governed irrigation systems' adaptations result in varying irrigation performance (Cox \& Ross, 2011; Janssen \& Anderies, 2013). Performance depends on the interactions between geography, technology, and institutions (Ostrom, 1992; Poteete et al., 2010; Hansen et al., 2011).

One way that irrigators might be able to adapt to climate change is through the adoption and adaptation of property rights to water (Meinzen-Dick, 2014; Gupta \& Lebel, 2010). Research on human behavior indicates that both moral and economic incentives can influence collective action (Ostrom, 2005). Institutions such as water rights provide both economic and moral 
information to water users, and therefore institutions should be influential in determining irrigation performance because of their capacity to reveal information about the potential economic and social outcomes of alternate decisions. While the water rights regime in Colorado - Prior Appropriation (PA) - is unique to the Western US, some portions of Canada, and Australia, the ultimate effect of the regime is to create a "priority system" where irrigators are ranked based on a rule of "first capture" (Kenney, 2005; Libecap, 2011) and higher ranking "senior" users may take water prior to and for longer periods than "junior" users, who sometimes receive no surface water at all. Property rights in the United States generally and water rights in Colorado especially are strongly enforced by the court system, and so one would expect property rights to water to dominate irrigation in the SLV and in other contexts of strong enforcement.

However, there is a tongue-in-cheek saying in the SLV: "It's better to be upstream with a shovel than downstream with a water right." The aphorism highlights the importance of being able to divert water before other irrigators and thus deprive them of water. Similarly, in an extensive study of irrigation performance in Nepal, Lam (1998) finds that on irrigation systems themselves, upstream users ("head-enders") tended to access water more reliably than downstream users ("tail-enders"). At a larger scale, downstream nations (e.g. Mexico, Egypt, Vietnam) also often find themselves in less powerful positions relative to their upstream counterparts (The United States, Ethiopia and Sudan, China, respectively). Between US states, many lawsuits brought between states over water involve the downstream state suing the upstream state for allegedly taking more than its fair share (e.g. Texas v. New Mexico and Colorado; Florida v. Georgia; Mississippi v. Tennessee). Experiments find that upstream users act as "stationary bandits", depriving downstream users of water (Janssen et al., 2011).

That said, in a snowmelt driven system, being too far upstream is hypothetically possible. If diverting from a tributary rather than a mainstem, fewer streams aggregate and therefore reduce the reliability of flow (Xu et al., 2014b). And if catchment sizes are smaller, less water is available (USDA, 2012). There are instances in Colorado where upstream users have senior rights but are not able to divert water because it simply is not there (denoted as a "futile call"). Therefore, the hydrograph of the stream from which water is diverted (USDA, 2012; Xu et al., 2014b), the number of irrigators diverting water upstream of a given user (Janssen et al., 2011; Lam, 1998), and available storage technology (Cody et al., 2015; Cox \& Ross, 2011; Smith, 2016) combine to influence physical water availability and therefore the relative role of water rights.

The literature has not come to agreement on the question of whether water rights or geography have more influence on irrigation performance and why that might be (Poteete et al., 2010). Here I look at the effect of water rights and position on the stream, controlling for important variables such as elevation, across a variety of watersheds where conditions are likely to be different in important ways (Alcon, et al., 2014). This analysis can inform the kinds of institutional interventions or support, if any, might be needed to adapt to a dryer climate and the some of the important contextual factors that could be involved (Mukhtarov, et al.; 2015). At a minimum, it will illuminate the extent to which water rights may be a lever of adaptation to drought. 
I evaluate five hypotheses, shown in Table 1. In general, I would expect these hypotheses to be true in any snowmelt dependent irrigation context, with the caveat that it is possible some factors - such as treaties and cultural norms - could create situations where these hypotheses do not hold. These hypotheses are evaluated for the period 1984-2015 on a completely sampled population of 696 irrigation systems, drawing on publically available data collected from the State of Colorado and the US Geological Survey. To ensure the sample has comparable observations, I use genetic matching procedures (Diamond \& Sekhon, 2013; Ho et al., 2007) to produce a final dataset of 402 irrigation systems. Because the variables of interest, water right priority and geographic factors, are time-invariant making fixed-effects analysis impossible, the time-variant data associated with each observation are averaged over the study period. To ease interpretation of results, the data are then standardized (variables are centered at their means, then divided by the variable's standard deviation) except for the dichotomous and categorical variables. Regression analyses are then performed on this standardized cross sectional data following Gujarati \& Porter (2009). Quantitative data and results are complimented by field visits over the period of 2012-2016. The methods section below elaborates this approach, and further details are contained in Section 2.2-2.3 of the supplementary materials.

Table 1. The five hypotheses with their essential rationales and some citations supporting the hypotheses.

\begin{tabular}{|l|l|l|}
\hline Hypothesis & Rationale & Citations \\
\hline $\begin{array}{l}\text { H1. All else equal, there is a } \\
\text { positive relationship between } \\
\text { irrigation performance and higher } \\
\text { water right priority. }\end{array}$ & $\begin{array}{l}\text { Senior rights lead to a longer } \\
\text { duration of water availability and } \\
\text { more reliable water supply. }\end{array}$ & $\begin{array}{l}\text { Cody et al., 2015; Kamran \& } \\
\text { Shivakoti, 2013; Kenney, 2005; } \\
\text { Libecap, 2011; Smith, 2016; } \\
\text { Torpey-Saboe, et al., 2015; Xu et al., } \\
\text { 2014a, 2014b }\end{array}$ \\
\hline $\begin{array}{l}\text { H2. All else equal, there is a } \\
\text { negative relationship between } \\
\text { irrigation performance and the } \\
\text { number of diversions upstream of a } \\
\text { given diversion. }\end{array}$ & $\begin{array}{l}\text { The more irrigators upstream of a } \\
\text { given user the larger the chance of } \\
\text { over-depletion. }\end{array}$ & $\begin{array}{l}\text { Janssen et al., 2011; Janssen \& } \\
\text { Anderies, 2013; Kadirbeyoglu \& } \\
\text { Ozertan, 2015; Lam 1998; Meinzen- } \\
\text { Dick, 2007; Zwart \& Leclert, 2010 }\end{array}$ \\
\hline $\begin{array}{l}\text { H3. All else equal, there is a } \\
\text { positive relationship between } \\
\text { irrigation performance and } \\
\text { catchment size. }\end{array}$ & $\begin{array}{l}\text { Smaller catchments have less } \\
\text { snowpack, which leads to lower } \\
\text { stream flow and shorter durations of } \\
\text { water availability. }\end{array}$ & Lam 1998; USDA, 2012 \\
\hline $\begin{array}{l}\text { H4. All else equal, there is a } \\
\text { negative relationship between } \\
\text { irrigation performance and } \\
\text { diverting from a tributary. }\end{array}$ & $\begin{array}{l}\text { Tributaries aggregate flows from } \\
\text { fewer streams and are therefore have } \\
\text { higher flow variability. }\end{array}$ & Lam 1998; Xu et al., 2014b \\
\hline $\begin{array}{l}\text { H5. All else equal, the influence of } \\
\text { water rights will depend on } \\
\text { climate, geography, culture, and } \\
\text { higher level policy. }\end{array}$ & $\begin{array}{l}\text { Water rights depend on available } \\
\text { water supply, are administered by } \\
\text { people in a broader social context, } \\
\text { and are subject to higher level policy }\end{array}$ & $\begin{array}{l}\text { Cox, 2014; Kamran \& Shivakoti, } \\
\text { 2013; Kenney, 2005; Lam, 1998; } \\
\text { Ostrom, 2005; Smith, 2016; Tang \& }\end{array}$ \\
\hline
\end{tabular}

Results indicate that while water right priority rank has a significantly positive effect for all dependent variables, its influence depends on several factors, including catchment area, whether the system diverts from a tributary, available precipitation, and number of upstream diversions. Overall, increasing catchment area is as influential as water right priority rank. Other signals are not as strong. Diverting from a tributary is significantly harmful for percent maximum volume diverted and percent area irrigated, but not months of active diversion. Many upstream diversions is only significantly harmful for percent maximum volume diverted. Finally, PA created stark inequalities among irrigators in the extreme 2002 drought, especially among those 
lacking storage, with senior users receiving their full allocation of water (albeit for a shorter period than normal) and junior users receiving no water. In a context without savings, insurance, credit, and/or access to secondary sources of income or food, PA could generate significant social discord, potentially leading to hunger, migration, and/or physical conflict.

\subsection{Theoretical Approach}

The Institutional Analysis and Development (IAD) framework (Poteete et al., 2010) is useful for examining the question of how the institutional and physical dimensions of a Social-Ecological System (SES) interact to influence irrigation performance. In addition to being designed to analyze institutions, the IAD framework has well defined and clearly separated variable concepts and easily accommodates different theories (Sabatier, 2007). The IAD framework separates contextual variables into three categories: Biophysical, Institutional, and Socio-Economic (i.e. "attributes of the community"). These contextual variables influence actors who make decisions in an "Action Arena", which produce outcomes that feedback on the contextual variables. Furthermore, related scholarship (Cox \& Ross, 2011; Cox, 2014; Smith, 2016) uses the IAD framework as a basis for investigations into similar questions in geographically proximate and institutionally similar systems. This study complements this work using similar methods. Figure 1 illustrates a highly simplified version of the IAD framework and where the variables under consideration fit into it. Figure 1 is more applicable to my specific research problem because it locates the variables in physical space. Although there are feedbacks over time in any SES, Figure 1 omits them because the variables under consideration here are largely unresponsive to these feedbacks over the study period because they are either legally, financially, or physically limited.

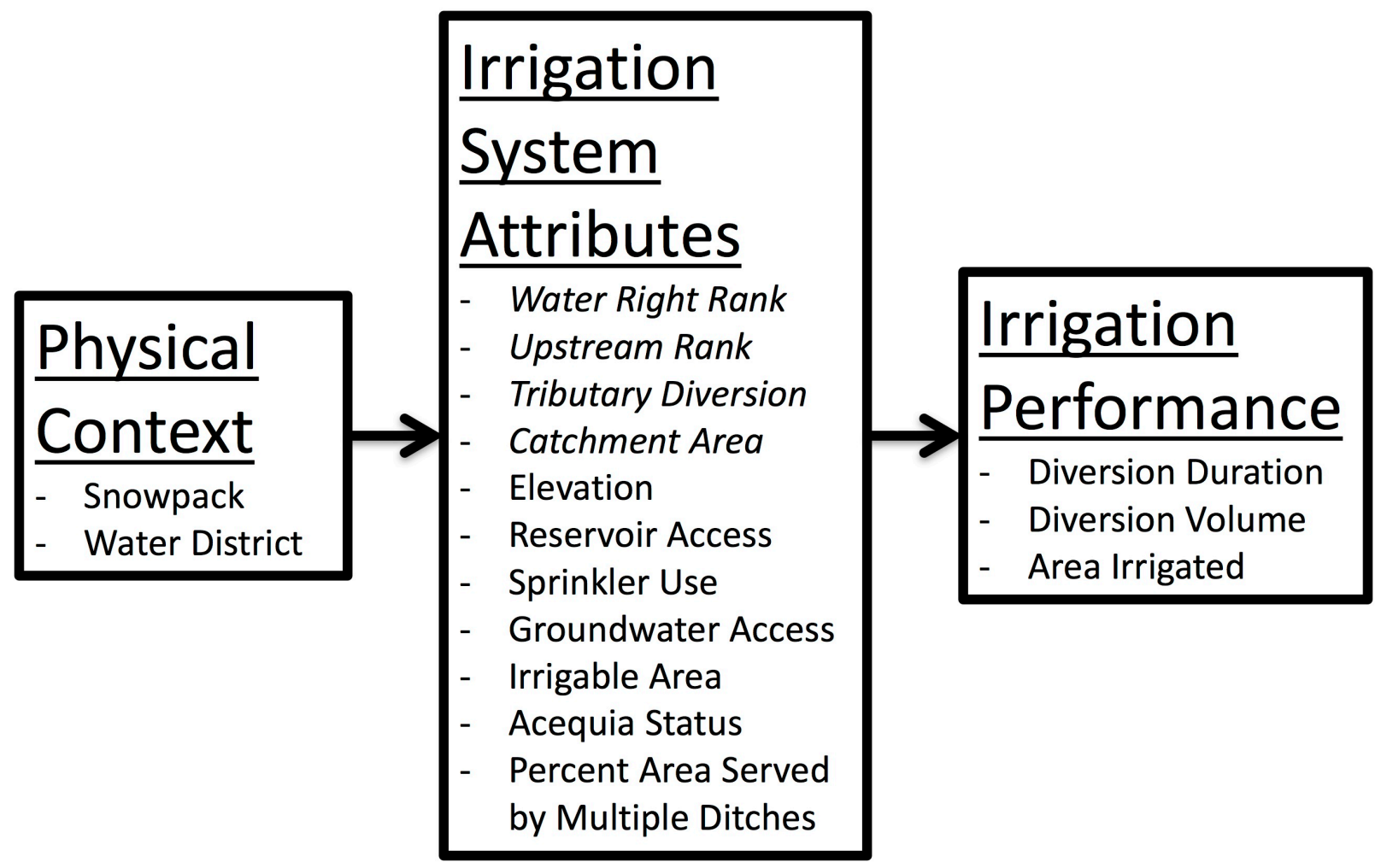


Figure 1. The theoretical relationships between the key variables in a single irrigation season are shown in a modification of the IAD framework (Ostrom, 2005). Normally, IAD considers Context, an Action Arena, Outcomes, and Evaluative Criteria. Here, context has been simplified to Physical Context; Irrigation System Attributes are the Action Arenas; Outcomes are represented by Irrigation Performance; and Evaluative Criteria have been omitted. The variables in italics are those of primary interest to the hypotheses.

Closely related to the IAD framework is CPR theory (Ostrom, 2005), which posits that human users of CPRs can act collectively to create institutions which evolve over time to manage their use of said CPRs and that long-lived commons management regimes share essential features related to the evolution of cooperation (Wilson et al., 2013). Irrigation systems, like all CPRs, face problems with difficulty of exclusion (access to the resource is difficult to restrict) and subtractability (the resource is consumed and made unavailable to others) (Poteete et al., 2010). CPR theory focuses on complex human-environment interactions and has explanatory power in experimental, survey, and field studies of irrigation (Ostrom, 1992, 2005; Poteete et al., 2010). Moreover, I use CPR theory to lead preliminary questions, select variables, formulate hypotheses, and check inferences.

\subsection{Climate Change and Irrigation in the San Luis Valley}

Climate change is expected to negatively affect irrigated agriculture, especially in arid regions reliant on snowmelt (Wheeler \& von Braun, 2013; Gleick, 2003; Vicuña et al., 2012;

Villamayor-Tomas, 2012). Climate change does this through increases in temperature and therefore crop water demand (potentially offset by $\mathrm{CO}_{2}$ fertilization [Deryng et al., 2016]), and in arid areas through decreases in precipitation (Lukas et al., 2014). Combined, temperature and precipitation changes mean that snowmelt timing and volume are also changed, increasing the challenge for irrigators whose crops rely on snowmelt as opposed to rain, such as those in the SLV. Spring snowpack is decreasing in volume and melting earlier in the SLV and across Colorado due to increasing temperature and dust on snow, with decreasing stream flow in the Rio Grande basin especially (Lukas et al., 2014). Indeed, there have already been observed changes in temperature, and therefore frost-free season, growing degree day patterns, and onset of peak stream flow (Mix et al., 2011; Mix et al., 2012). That said, increasing temperatures can extend the growing season, a historical limitation in the SLV, especially for high elevation farms. However, earlier snowmelt will complicate the potential benefits of an extended frost-free period, in that it will produce a longer period over which irrigators will need to rely on surface reservoir storage or groundwater, especially later in the season. If storage water can be accessed, farms will likely see net benefits from increased temperatures.

Regardless of the pace of climate change and what might happen in the SLV long term, drought - defined by lower than average water availability - is harmful for irrigators and will continue to threaten irrigation. Important for this analysis, in 2002 the SLV experienced the worst drought on record, and perhaps in the past 500 years (Woodhouse et al., 2012). The subsequent years have also been unusually dry. Irrigated acreage in 2002 was reduced $40 \%$ from 1997 levels. The Rio Grande carried $24 \%$ the annual average daily flow at its most important gage in 2002. Most critically, there was no snowmelt after May in 2002 during peak crop water demand (Cody et al, 2015). This drought and the subsequent arid decade can be used to assess the role of water rights and geography under different climatic conditions. See Section 1.3 in the supplementary materials for more details on climate change in the SLV. 


\subsection{Water Rights, Water Management, and Cultural Norms in the San Luis Valley}

The following section describes the water rights regime, how the state administers water in the SLV, and relevant historical factors that influence water allocations. Establishing, monitoring and enforcing property rights have been shown to be an efficient way of sustaining CPRs in theory (Ostrom, 2005), through markets (Grafton et al., 2011), and using case studies (Agrawal, 2013). However, there is disagreement over their influence, given that de jure rights may not in fact be honored and that geographic and technological factors are also highly influential (Meinzen-Dick, 2007; Kadirbeyoglu \& Ozertan, 2015; Ostrom, 1992). Additionally, without mechanisms to quantify and monitor withdrawals from a CPR as well as sanction violators, access rights to that CPR may not be effective from a practical standpoint (Torpey-Saboe, et al., 2015). The SLV offers a chance to study the influence of property rights due to the similarities and differences in how water rights are applied within the SLV. Different watersheds have different historical water rights regimes and different obligations with regards to the Rio Grande Compact (RGC), which together may influence the administration of water rights.

\section{Water Rights: Prior Appropriation}

Over 150 years ago, American farmers in the Western United States adopted the Doctrine of Prior Appropriation in water rights. When the irrigation systems were founded, those systems that first began using water beneficially retained a priority right to the water over those who diverted water at a later time (Kenney, 2005). PA is often summarized as the principle of "first in time, first in right". In practice, this is a non-injury principle, whereby no junior water user - one with a lower priority - may impinge on the full exercise of the water right held by any senior water user - one with a higher priority. Thus, on a given stream system (denoted in Colorado as a Water District), the oldest water right receives its full allocation of water as long as it physically can, while more junior systems may not receive their full allocation, or any water at all, depending on streamflow and the rights of others. Additionally, the maximum volume that can be diverted by a given irrigation system at a given time is limited by the water rights held by that system. This diversion rate (given in cubic feet per second) was determined at the time the right was claimed, limited by statute to the amount that could be beneficially used for irrigation, a precaution to avoid waste (Kenney, 2005). The maximum diversion rate of the water right, therefore, does not usually influence irrigation performance as it is measured in this study since the maximum diversion rate represents an appropriate amount for the land.

Importantly, the water rights regime is informally enforced by farmers themselves and formally enforced by state agents. PA therefore poses real limits to use (Torpey-Saboe, et al., 2015). Recent studies have found that PA is influential today and is expected to be influential under climate change on the Snake River in Idaho (Xu et al., 2014a; Xu et al., 2014b). Ongoing activity in Colorado's Water Courts implies that adherence to these water rights is expected by irrigators and consequences follow from a lack of implementation and violations of the law. Private rights to water are culturally important among irrigators and are part of the platform of the Republican Party (Goldstein \& Hudak; 2017). Finally, irrigators report that priority administration is the cornerstone of water management in the SLV.

Water right priorities are implemented in real time at the diversion structure of the irrigation system; the point at which the water leaves the natural course of the stream and enters a manmade channel. Once in the channel, priority is essentially irrelevant except in circumstances 
where more than one water right priority exists. To manage the water once it is diverted, irrigation systems in the SLV exhibit a range of institutional formality; from completely unwritten oral governance traditions to non-profits with articles of incorporation, bylaws, and shareholders (almost always the irrigators using the canal system, except in the case of absentee land owners). In instances where shares are used to allocate water on the irrigation system, the water rights themselves can be transferred to the corporation, giving farmers the rights to use the amount of water represented by their shares, which can be bought and sold. When water rights are not transferred to a ditch company, they are retained on the deeds to the lands which may be irrigated by the ditch or ditches in question. Although this ditch-level management is interesting, it is beyond the scope of this paper because these factors will have no influence on the duration or volume of water diversion, and only marginal influence on the acreage irrigated.

\section{Water Management: The Rio Grande Compact, Water Districts, and the Closed Basin}

Below I describe key features of the eight Water Districts in the SLV. Despite PA's place in the Colorado Constitution, there are open questions in the literature as to whether PA influences irrigator behavior given the host of new environmental regulations, government agencies, interstate agreements, technological interventions, court rulings privileging the public interest, and the costs associated with monitoring and enforcement of water rights (Benson, 1998; Benson, 2012; Tarlock, 2000; Tarlock, 2001). In the SLV, the RGC is one such obstruction to PA. Because of the peculiarities of how the RGC is administered, the state line with New Mexico acts as a kind of "super-senior" that is always owed water, with the amount varying depending on the level of the river at an upstream gage (Paddock, 2013). The amount owed is divided between the Rio Grande (WD20) and Conejos River (WD22), meaning these two stream systems always have water flowing to their respective terminus. Because only these two of the eight Water Districts in the SLV are covered by the Compact (WD20 and WD22), it will be possible to determine how influential water rights are despite the enforcement of the RGC by comparing the influence of water rights across the different Water Districts. Table 2 shows how the Water Districts compare across several key variables of interest in this study.

Table 2. Descriptive statistics of some key variables of Water Districts and the irrigation systems and counties associated with them. The exact median farm size was not available from the US Department of Agriculture (USDA, 2014), however the data gave a range which contained the median.

\begin{tabular}{|c|c|c|c|c|c|c|c|c|}
\hline & $\begin{array}{l}\text { Water } \\
\text { District } 20\end{array}$ & $\begin{array}{l}\text { Water } \\
\text { District } 21\end{array}$ & $\begin{array}{l}\text { Water } \\
\text { District } 22\end{array}$ & $\begin{array}{l}\text { Water } \\
\text { District } 24\end{array}$ & $\begin{array}{l}\text { Water } \\
\text { District } 25\end{array}$ & $\begin{array}{l}\text { Water } \\
\text { District } 26\end{array}$ & $\begin{array}{l}\text { Water } \\
\text { District } 27\end{array}$ & $\begin{array}{l}\text { Water } \\
\text { District } 35\end{array}$ \\
\hline Major Stream & Rio Grande & $\begin{array}{l}\text { Alamosa- } \\
\text { La Jara }\end{array}$ & $\begin{array}{l}\text { Conejos } \\
\text { River }\end{array}$ & $\begin{array}{l}\text { Culebra } \\
\text { Creek }\end{array}$ & $\begin{array}{l}\text { San Luis } \\
\text { Creek }\end{array}$ & $\begin{array}{l}\text { Saguache } \\
\text { Creek }\end{array}$ & $\begin{array}{l}\text { Carnero } \\
\text { Creek }\end{array}$ & $\begin{array}{l}\text { Trinchera } \\
\text { Creek }\end{array}$ \\
\hline $\begin{array}{l}\text { Water District } \\
\text { Acreage }\end{array}$ & $1,603,668$ & 325,481 & 496,485 & 456,715 & 515,552 & 536,894 & 165,188 & 273,930 \\
\hline $\begin{array}{l}\text { Stream Fully } \\
\text { Depleted }\end{array}$ & No & Yes & No & Yes & Yes & Yes & Yes & Yes \\
\hline Within Closed Basin & Partial & No & No & No & Yes & Yes & Yes & Partial \\
\hline $\begin{array}{l}\text { Rio Grande Compact } \\
\text { Administration }\end{array}$ & $\begin{array}{l}\text { Delivery } \\
\text { Obligations }\end{array}$ & $\begin{array}{l}\text { Non- } \\
\text { Tributary }\end{array}$ & $\begin{array}{l}\text { Delivery } \\
\text { Obligations }\end{array}$ & $\begin{array}{l}\text { Non- } \\
\text { Tributary }\end{array}$ & $\begin{array}{l}\text { Closed } \\
\text { Basin } \\
\end{array}$ & $\begin{array}{l}\text { Closed } \\
\text { Basin }\end{array}$ & $\begin{array}{l}\text { Closed } \\
\text { Basin }\end{array}$ & $\begin{array}{l}\text { Non- } \\
\text { Tributary }\end{array}$ \\
\hline $\begin{array}{l}\text { Number of Ditch } \\
\text { Systems }\end{array}$ & 193 & 75 & 105 & 63 & 91 & 106 & 35 & 28 \\
\hline $\begin{array}{l}\text { Average Ditch System } \\
\text { Acreage }\end{array}$ & 1761.2 & 1089.6 & 1035.4 & 427.5 & 397.8 & 256.0 & 375.2 & 1389.1 \\
\hline $\begin{array}{l}\text { Percent Ditch } \\
\text { Systems Acequias }\end{array}$ & 6.4 & 35.7 & 43.3 & 43.3 & 0 & 0 & 15.6 & 11.1 \\
\hline $\begin{array}{l}\text { Percent Ditch } \\
\text { Systems with Wells }\end{array}$ & 21.76 & 57.3 & 37.1 & 9.5 & 30.8 & 24.5 & 40.0 & 28.6 \\
\hline $\begin{array}{l}\text { Percent Ditch } \\
\text { Systems with } \\
\text { Reservoir } \\
\end{array}$ & 26.4 & 4.0 & 52.4 & 4.8 & 0 & 0 & 0 & 3.6 \\
\hline
\end{tabular}




\begin{tabular}{|l|l|l|l|l|l|l|l|l|}
\hline $\begin{array}{l}\text { Percent Ditch } \\
\text { Systems Diverting } \\
\text { from Tributary }\end{array}$ & 30.6 & 13.3 & 5.7 & 73.0 & 68.1 & 24.5 & 2.9 & 82.1 \\
\hline $\begin{array}{l}\text { Average Ditch System } \\
\text { Catchment Acreage }\end{array}$ & 309,598 & 121,004 & 216,159 & 45,565 & 35,411 & 222,208 & 54,000 & 58,555 \\
\hline Major Counties & $\begin{array}{l}\text { Alamosa, } \\
\text { Rio Grande }\end{array}$ & Conejos & Conejos & Costilla & Saguache & Saguache & Saguache & $\begin{array}{l}\text { Alamosa, } \\
\text { Costilla }\end{array}$ \\
\hline $\begin{array}{l}\text { County Number of } \\
\text { Farms 2012 }\end{array}$ & $322 ; 377$ & 605 & 605 & 251 & 277 & 277 & 277 & $322 ; 251$ \\
\hline $\begin{array}{l}\text { County Median Farm } \\
\text { Acreage Range 2012 }\end{array}$ & $\begin{array}{l}140-179 ; \\
140-179\end{array}$ & $100-139$ & $100-139$ & $70-99$ & $260-499$ & $260-499$ & $260-499$ & $140-179 ;$ \\
\hline $\begin{array}{l}\text { County Mean Farm } \\
\text { Net Income 2012 }\end{array}$ & $\begin{array}{l}\$ 69,445 ; \\
\$ 88,198\end{array}$ & $\$ 18,200$ & $\$ 18,200$ & $\$ 23,436$ & $\$ 100,549$ & $\$ 100,549$ & $\$ 100,549$ & $\begin{array}{l}\$ 69,445 ; \\
\$ 23,436\end{array}$ \\
\hline
\end{tabular}

Further distinguishing the Water Districts, there is an endorheic basin the SLV called the Closed Basin, into which the streams in the North of the SLV drain (Thiros et al., 2010). This water never reaches the Rio Grande via the surface, and instead recharges groundwater in the unconfined aquifer from which many irrigators in the SLV withdraw, indirectly decreasing the flow of the Rio Grande (Cody et al., 2015). Throughout the modeling process groundwater access is accounted for using a dummy variable indicating whether any land within the service area of the irrigation system is irrigated using groundwater. These Northernmost Water Districts (WD25, WD26, and WD27) are not administered as part of the RGC (Paddock, 2013). There are many endorheic basins in the Western United States and the world, and PA is applied in the same way in closed and open basins: first in time, first in right. The meaningful difference in the SLV is that this Closed Basin is not administered as part of the RGC, a factor I account for in the models using Water District as a factor variable. The remaining three Water Districts (WD21, WD24, and WD35) have streams that are considered by the State Engineer to have historically not reached the Rio Grande, and are therefore deemed "non-tributary" to the Rio Grande, and thus are also not administered as part of the RGC (Paddock, 2013). See Figure 2 for a map of the Water Districts and the approximate Southern boundary of the Closed Basin. 


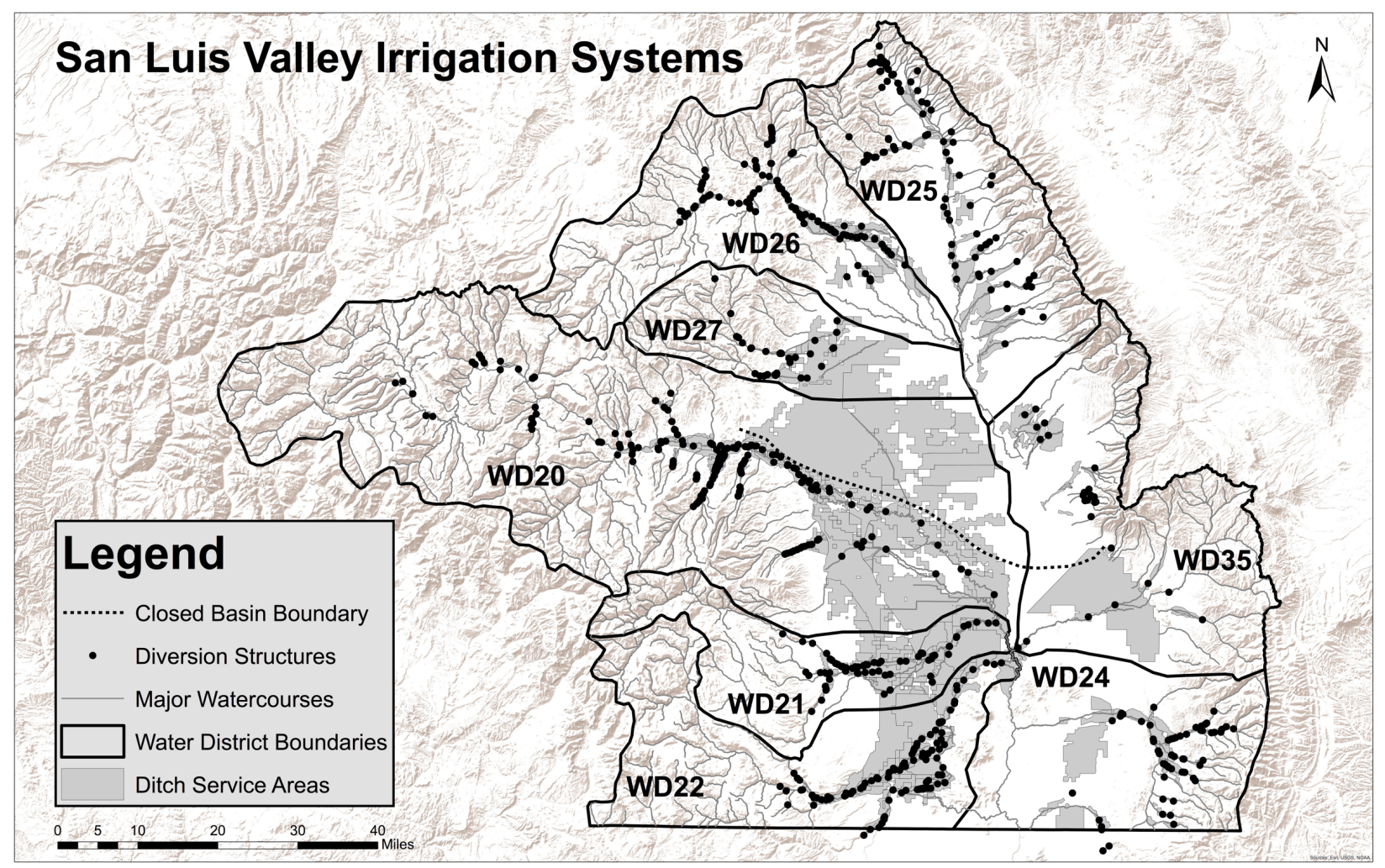

Figure 2. Map of the San Luis Valley, depicting Water Districts, major watercourses, diversion structures, ditch service areas, and approximate Closed Basin boundary (Colorado Division of Water Resources, n.d.; Thiros et al., 2010). See Section 1.1 and 1.2 in the supplementary material for more detail on Water District attributes.

\section{Cultural Norms: Acequias}

In addition to the differing hydrology and higher level policies of the Water Districts, there are differences in historical practices and cultural norms surrounding water allocation between them. PA was not the first water rights regime in the SLV. American settlers were preceded by 20-30 years by the Spanish in the Southern portions of the valley (Rivera, 1998; Rodriguez, 2006), especially in WD21, WD22, and WD24. These irrigators followed a different allocation mechanism, inherited from the Moorish occupation of Spain, whereby a rotational sharing arrangement, a repartamiento, was negotiated among the different acequias, or ditch systems, each year before irrigation began. The farmers, or parcientes, would also negotiate sharing arrangements between each other on a given acequia (Cox \& Ross, 2011; Cox, 2014). When water was especially scarce, only the best lands were irrigated and the produce shared among the families in the community. Historically distinct from the American system, water was considered public property, it was allocated based on need, and decisions were made using a one-landownerone-vote system. Many of these ditch-level traditions still apply to the Hispanic irrigation systems that exist today, though there is an ongoing coevolution of ditch-level operations between Hispanic and Anglo systems. Acequias have been slower to adopt high capacity groundwater wells, viewing them as an imposition on their neighbors' rights to the water they share. It is also the case that the acequias, especially since World War II, have been reluctant and sometimes unable to integrate into the capital market, adopt sprinkler irrigation, and enroll in government farming programs. Acequias are generally smaller, limiting their total productive capacity. However, acequias tend grow a greater diversity of crops, have better maintained soil, a higher water table, require less expensive machinery, use animal fertilizers, and apply fewer 
chemical pest and weed controls to their land. To account for these factors in the modeling, acequia status is included as a dummy variable, determined by whether the irrigation system has a Hispanic name (e.g. la del rio, Salazar ditch, acequiacita, etc.).

Despite these differences, the Anglo and Hispanic systems are fundamentally similar: they divert water from a stream and bring it to farmland through a gravity fed network of canals and ditches. Crucial for this investigation, both types of system are treated the same by the state at the point of diversion. Over time, the Americans have, more or less successfully, forced the private water rights regime of PA onto the Spanish customary rights (Rivera, 1998; Rodriguez, 2006). However, while acequias nominally follow PA, the acequia community in Colorado does not openly discuss whether they follow PA, their traditional repartamiento system, or some hybrid of the two. This study should be able to detect any differences in the influence of PA among the acequias by interacting this variable with water right priority. Comparisons between acequias and the Anglo systems allow for transferability of results and illustrate how water rights interact with different historical origins. Many globally relevant systems host distinct but coevolving property rights regimes, sometimes imposed by colonial powers (Kamran \& Shivakoti, 2013; Mukhtarov, et al., 2015; Tang \& Gavin, 2015).

\section{Materials and Methods}

Careful case selection for "natural experiments" is increasingly encouraged when research questions cannot be answered using laboratory or similar experiments or modeling, when study systems involve many different biophysical and social data, and when data are difficult or impossible to acquire or aggregate (Poteete et al., 2010). Natural-experiments such as this study require data about numerous potentially confounding variables, and these data are seldom available at the same unit of analysis or resolution. However, the SLV overcomes many of these challenges due to the richness of its public data, the stability of the units of analysis, and four years of site visits by the author to ground truth the data and analysis.

\subsection{Data Collection and Variable Selection}

Data were collected from various public sources, primarily the Colorado Department of Natural Resources' Decision Support Systems and Google Earth Engine. Time-variant data from 19842015 were collected for monthly snowpack, monthly temperature, annual stream flow, amount of water diverted by irrigation systems each month, and acres irrigated each year. Time-invariant data such as diversion location, groundwater access, irrigated area, elevation, water right priority, and catchment area were also collected from these public sources.

Variables used in the analysis were selected based on their influence on irrigation performance in preliminary analyses, including: correlations, pair-wise regressions, and ANOVA. Variables such as the number of water rights, the total volume of water rights, latitude, aspect, slope, temperature, and year the irrigation system was founded were evaluated for their influence on irrigation performance and included in preliminary analyses. However, these variables were not deemed sufficiently explanatory or produced unacceptable multicollinearity. Variables included in the analysis are indicated in Table 3 . See Table 1 in the supplementary material for more information on variable development and measurement.

Table 3. Table showing variable included in the analysis, their shorthand name, and their form. 


\begin{tabular}{|c|c|c|c|}
\hline Variable & Shorthand Name & Variable Type & Variable Units \\
\hline \multicolumn{4}{|c|}{ Independent Variables (directly relevant to the hypotheses) } \\
\hline Water Right Priority Rank & PriorRank & Ordinal & Rank \\
\hline Upstream Rank & UpRank & Ordinal & Rank \\
\hline Diverts from a Tributary Stream & Trib & Binary & None \\
\hline Catchment Area of the Diversion Structure & CatchArea & Continuous & Acres \\
\hline \multicolumn{4}{|c|}{ Control Variables (important for the outcomes but not directly relevant to the hypotheses being tested) } \\
\hline Snow Water Equivalent at Nearest SNOTEL & $S W E$ & Continuous & Inches \\
\hline Elevation of Diversion Structure & Elev & Continuous & Meters \\
\hline Majority Sprinkler Irrigated in Majority of Years & Sprink & Binary & None \\
\hline Percent Years Accessing Surface Reservoir & Res & Percentage & Percentage \\
\hline Acequia Status & Acequia & Binary & None \\
\hline Acreage of Irrigation System & Area & Continuous & Acres \\
\hline Groundwater Access & Ground & Binary & None \\
\hline Percent Area Served by Multiple Ditch Systems & PerMulti & Percentage & Percentage \\
\hline Water District of Diversion Structure & $W D$ & Categorical & None \\
\hline \multicolumn{4}{|l|}{ Dependent Variables (outcomes being evaluated) } \\
\hline Months of Diversion Activity & $M D A$ & Continuous & Months \\
\hline Percent Maximum Diversion & $P M D$ & Percentage & Percentage \\
\hline Percent Maximum Irrigated Area & PMIA & Percentage & Percentage \\
\hline
\end{tabular}

To process the data, I first eliminate observations with missing data, reducing my observations from 694 to 639 . Observations were excluded because variables were missing in the state database and the ArcGIS 10.4 was unable to compute watershed areas for some observations. I then use a genetic matching algorithm to ensure my dataset has comparable observations and to reduce model dependence (Diamond \& Sekhon, 2013; Ho et al., 2007). This reduces my dataset from 639 irrigation systems to 402 . To ease the interpretation of results, I then standardize the data by mean-centering each variable and dividing each variable by its standard deviation (except the dichotomous and categorical variables). See Section 2.3 in the supplementary material for more information on data processing, including a full description of the matching procedure.

There are some limitations to the data. For example, the study lacks any direct data on the wealth available to irrigation systems. However, the area of irrigation systems is a proxy for the total wealth available to that system. As the size of an irrigation system increases, the wealth available to that system for maintenance and operations also increases, generating economies of scale as the fixed costs of collective management of the ditch system diminish as a percentage of the overall farm revenues. Larger systems are also more able take out debt for infrastructure projects, since land is often used as collateral in agricultural contexts. Finally, larger systems are more politically powerful in the SLV because they make up such a high percentage of overall agricultural production, and this political power can be used to access resources from the federal and state governments. The acequia variable also provides some socio-economic information as well, since those systems tend to have smaller farms, lower yields per acre, and less political power. System size and acequia status also correlate with the number of irrigators, an important variable for which data is also unavailable.

\subsection{Analytical Methods}

To analyze the data, I employ regression methods using two-tailed significance tests. Following Gujarati \& Porter (2009), I evaluate several between-estimator regressions which average data over time for the entire time series. I also run regressions on data averaged over quintile subsets by Snow Water Equivalent (SWE) (the middle quintile contains eight years of data, the others six). Regressions were also run on data from the year 2002 (Tobit), the worst drought on record. Model diagnostics were performed. Heteroscedasticity and auto-correlation robust standard 
errors were reported for following Gujarati \& Porter (2009) and Zeileis (2004) where appropriate. Models without interactions on the matched, time-averaged data and the matched, time-averaged data subset by SWE took the form:

$$
\begin{gathered}
y_{i}=\beta_{0}+\beta_{1} \text { PriorRank }_{i}+\beta_{2} \text { UpRank }_{i}+\beta_{3} \text { Trib }+\beta_{4} \text { Acequia }_{i}+\beta_{5} \text { CatchArea }_{i}+\beta_{6} \text { Area }_{i} \\
+\beta_{7} \text { Elev }_{i}+\beta_{8} \text { SWE }_{i}+\beta_{9} \text { Res }_{i}+\beta_{10} \text { PerMulti }_{i}+\beta_{11} \text { Ground }+\beta_{12} \text { Sprink }_{i} \\
+\beta_{13} \text { WD }_{i}+\varepsilon_{i}
\end{gathered}
$$

When regressing the dependent variables percent maximum diversion and months of active diversion, the independent variables groundwater access, sprinkler use, and percent area irrigated by multiple ditch systems were excluded, since these would not impact those outcomes. Models with interactions and for the year 2002 are of essentially the same form and use data from 2002 only where appropriate. See Section 3.2 of the supplementary material for more information on the model forms.

\section{Results}

Results from regressions on data averaged over the study period are presented in Table 4. In agreement with the first hypothesis, results show that higher ranked water rights are consistently and significantly associated with better irrigation performance. In agreement with the second hypothesis, a larger catchment area is also consistently significantly associated with better irrigation performance. The third and fourth hypotheses - that diverting from a tributary and diverting below many irrigators are harmful, respectively - are essentially supported, though less strongly than the first two hypotheses. Finally, in agreement with the fifth hypothesis, several other variables significantly interact with water right priority to mediate priority's effect on

\begin{tabular}{|c|c|c|c|}
\hline \multicolumn{4}{|c|}{ Regression Output from Matched Data Averaged over 1984-2015 } \\
\hline & $\begin{array}{l}\text { Percent Area } \\
\text { Irrigated } \\
(1)\end{array}$ & $\begin{array}{l}\text { Percent Maximum Volume } \\
\text { Diverted } \\
(2)\end{array}$ & $\begin{array}{l}\text { Months of Active } \\
\text { Diversion } \\
\text { (3) }\end{array}$ \\
\hline Priority Rank & $\begin{array}{c}0.1828^{* * *} \\
(0.0449) \\
\end{array}$ & $\begin{array}{l}0.3621^{* * *} \\
(0.0381) \\
\end{array}$ & $\begin{array}{l}0.5223^{* * *} \\
(0.0420) \\
\end{array}$ \\
\hline Upstream Rank & $\begin{array}{l}-0.1230^{*} \\
(0.0688)\end{array}$ & $\begin{array}{l}-0.1485^{* *} \\
(0.0590)\end{array}$ & $\begin{array}{l}-0.0933 \\
(0.0784) \\
\end{array}$ \\
\hline Tributary & $\begin{array}{c}-0.4352^{* * *} \\
(0.1304)\end{array}$ & $\begin{array}{l}-0.2576^{* *} \\
(0.1135)\end{array}$ & $\begin{array}{l}-0.0616 \\
(0.1210) \\
\end{array}$ \\
\hline Acequia & $\begin{array}{l}-0.0439 \\
(0.1440)\end{array}$ & $\begin{array}{l}-0.0513 \\
(0.1221)\end{array}$ & $\begin{array}{l}-0.1461 \\
(0.1219)\end{array}$ \\
\hline Catchment Area & $\begin{array}{l}0.1768^{* *} \\
(0.0874) \\
\end{array}$ & $\begin{array}{l}0.4785^{* * *} \\
(0.0570) \\
\end{array}$ & $\begin{array}{l}0.4261^{* * *} \\
(0.0578) \\
\end{array}$ \\
\hline Acreage & $\begin{array}{c}0.0014 \\
(0.0414) \\
\end{array}$ & $\begin{array}{l}0.0809^{* *} \\
(0.0388)\end{array}$ & $\begin{array}{l}0.1323^{* * *} \\
(0.0451)\end{array}$ \\
\hline Elevation & 0.0175 & 0.0296 & 0.0189 \\
\hline
\end{tabular}
irrigation performance.

Table 4. Between estimator regression outputs for the three dependent variables. 
Snow Water Equivalent

Percent Years Accessing Reservoir

Percent Acreage Potentially Irrigated by Multiple Ditch Systems

Groundwater

Sprinkler

Observations

$\mathrm{R}^{2}$

Adjusted $\mathrm{R}^{2}$

Residual Std. Error

\begin{tabular}{ccc}
$(0.0559)$ & $(0.0512)$ & $(0.0567)$ \\
\hline $0.1122^{* *}$ & $0.0947^{* *}$ & $0.1527^{* * *}$ \\
$(0.0522)$ & $(0.0467)$ & $(0.0492)$ \\
\hline $0.0862^{*}$ & $0.1396^{* * *}$ & $0.1884^{* * *}$ \\
$(0.0517)$ & $(0.0424)$ & $(0.0411)$ \\
\hline
\end{tabular}

$-0.0653$

$(0.0456)$

0.0621

$(0.1215)$

$-0.2940$

$(0.2184)$

400

0.3629

402

402

0.3311

0.5174

0.4832

$0.8179(\mathrm{df}=380)$
0.4617

$0.7337(\mathrm{df}=385)$

Note: Water District and constant omitted from the table but included in the regression. Heteroscedasticity and autocorrelation robust standard errors reported where appropriate. ${ }^{*} p<0.10 ;{ }^{* *} p<0.05 ;{ }^{* * *} p<0.01$

\subsection{Hypothesis 1: Water Rights Are Highly Influential}

As shown by Table 4, in all regressions performed on matched and standardized data averaged over the entire time series, increasing seniority of water right improves all measured irrigation outcomes with significance to $\mathrm{p}<0.01$. Water right priority rank is especially beneficial for months of active diversion, which would be expected given the nature of PA. Moving up a standard deviation on water right priority rank improves months of active diversion by 0.52 standard deviations. The weakest signal of water rights is on the average percent acres irrigated, which increases only 0.18 standard deviations for every standard deviation increase in water right priority rank. The coefficients on water right priority rank and catchment area are not significantly different to $\mathrm{p}<0.05$ in any of the three regressions in Table 4 .

\subsection{Hypothesis 2, 3 and 4: Diversion Location Matters for Performance}

H2: Catchment Area

Table 4 demonstrates that increasing catchment area improves all measured irrigation outcomes with significance to $p<0.05$. Moving up a standard deviation catchment area improves months of active diversion by 0.47 standard deviations. The weakest signal of catchment area is on the average percent acres irrigated, which increases only 0.18 standard deviations for every standard deviation increase in catchment area.

\section{H3. Tributary Diversion}

As shown in Table 4, diverting from a tributary significantly harms $(\mathrm{p}<0.01)$ the percentage of maximum irrigated acreage by 0.44 standard deviations. There is a smaller but still significant effect on percent of maximum volume diverted $(-0.26, p<0.05)$, and no significant effect on the months of active diversion.

\section{H4. Upstream Rank}

Table 4 demonstrates that upstream rank is the least supported hypothesis of the first four evaluated. Only for percent maximum volume diverted is the coefficient significant $(p<0.05)$. 
However, it is in the expected direction, albeit with relatively smaller magnitude $(-0.15)$ than the other variables evaluated.

\subsection{Hypothesis 5: Influence of Water Rights Depends on Other Variables}

In addition to the results on $\mathrm{H} 1-\mathrm{H} 4$, interactions were performed between water right rank and other relevant variables and regressions were performed on subsets of data (see Section 5, Figures 6-20 and Tables 3 and 4 in the supplementary materials). These analyses reveal that the effect of water rights depends on contextual factors. Of particular interest in an era of climate change is the influence of snowpack on the impact of water right priority rank, as shown in Figure 3.

Figure 3. Marginal effect plot of the interaction between water right ranking and SWE for percent acres irrigated. At lower and higher levels of SWE, water rights have no influence. The gray area represents bootstrapped 95\% confidence intervals, and the histogram on the x-axis shows the distribution of SWE across the units of observation. 


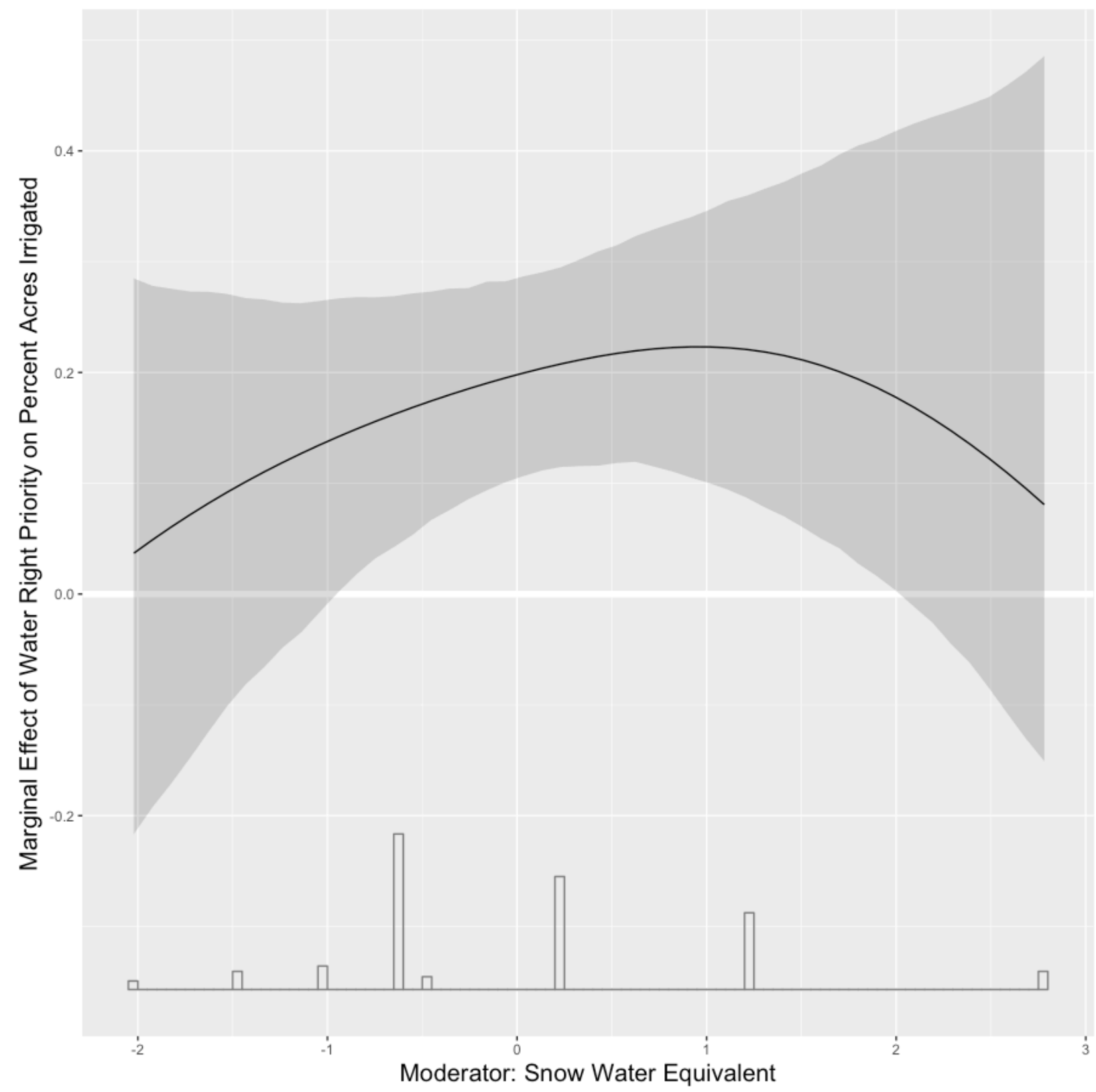

\section{Snowpack}

Tobit regressions run on data from the year 2002 (Table 5 in the supplementary materials) shows a similar pattern of results as those in Table 4 . Because the coefficients are not comparable to those in Table 4, the significance levels should be evaluated to compare differences. In 2002, water rights, catchment area, and surface reservoir access are all strongly significant determinants of irrigation performance $(\mathrm{p}<0.01)$. Upstream ranking and tributary diversion are not significant even to $\mathrm{p}<0.10$.

When data are subset by SWE (Tables 6-8 in the supplementary materials), a similar pattern to the results shown in Table 4 are apparent. More useful, however, are comparisons between different SWE subsets. For percent acres irrigated, the coefficient on water right priority ranking 
is significantly higher $(\mathrm{p}<0.05)$ for very dry and dry years when compared to wet years (but not very wet years). For percent maximum volume diverted, the coefficient on water right priority ranking is significantly higher $(p<0.05)$ for very dry years when compared to very wet and wet years and dry years when compared to wet years. There is no significant difference in the influence of water right priority ranking across subsets of years by climate for months of active diversion.

As Figure 3 demonstrates, water rights are also moderated by SWE on average. A similarly shaped curve exists for the other dependent variables (Figures 13 and 18 in the supplementary materials), although the marginal influence of water right priority ranking is almost uniformly significantly positive for the other dependent variables.

\section{Catchment Area}

The marginal effect of water right priority rank over different values of catchment area is significantly positive but declining as catchment area increases for all dependent variables (Figures 6,11 and 16 in the supplementary material). For percent area irrigated, the effect drops to be statistically indistinguishable from zero for catchment areas larger than a standard deviation above the mean catchment area. This same result of statistically zero marginal effect of water right priority rank is obtained only on the largest catchments for percent maximum volume diverted. For months of active diversion, the marginal effect of priority ranking is positive but declining over the range of values of catchment area.

\section{Tributary Diversion}

Interactions between water right priority rank and tributary diversion reveal significant differences between the influence of water right priority rank between systems diverting from a tributary and those diverting from a mainstem. Water right priority rank is significantly less influential $(\mathrm{p}<0.01)$ on months of active diversion $(-0.27)$ and volume diverted $(-0.26)$ when diverting from a tributary. A similar but less significant $(p<0.10)$ and less strong effect $(-.15)$ is seen for percent acres irrigated. These results are presented in Figures 10, 15, and 20 and Table 4 in the supplementary materials.

\section{Upstream Rank}

The marginal effect of water right priority rank over different values of upstream ranking is significantly positive but declining for all dependent variables except percent maximum volume diverted (Figures 7, 12 and 17 in the supplementary material). For percent maximum volume diverted, an inverted $\mathrm{U}$ shape is observed that is always above zero marginal effect. For percent area irrigated, the effect drops to be statistically indistinguishable from zero for upstream ranks larger than a standard deviation above the mean upstream rank. This same result of statistically zero marginal effect of water right priority rank is obtained only on the most downstream systems for months of active diversion.

\section{Cultural Heritage}

Interactions between water right priority rank and acequia status reveal no significant difference between the influence of water right priority rank between acequias and non-acequias. These results are presented in Figures 9, 14, and 19 and Table 3 in the supplementary materials. 
Higher Level Policy: The Rio Grande Compact

The interaction between water right priority rank and a dummy variable indicating whether a diversion is located on a stream subject to the RGC is not significant. The marginal effect of water right priority rank does not differ between ditches subject to the RGC and those not subject to the RGC. When water right priority rank is interacted with a categorical variable with three possible values - Closed Basin, Rio Grande Compact, and Non-Tributary - the marginal effect of water right priority rank is not significantly different between any of these categories. Only WD26, Saguache Creek, shows a significantly higher $(p<0.05)$ influence of water right ranking when compared to other Water Districts. This result exists for all dependent variables.

\section{Discussion}

\subsection{Hypothesis 1: Water Right Priority Rank}

Increasing water right priority rank is significantly associated with agriculturally meaningful improvements in irrigation performance. The consistently positive significant influence of increasing water right priority rank almost certainly because water rights are monitored and enforced between irrigators themselves and by the state (Castex, et al., 2015; Goldstein \& Hudak; 2017; Hurlbert \& Mussetta, 2016; Torpey-Saboe, et al., 2015). Contemporary literature in Western US suggests water rights matter (Xu et al., 2014a; Xu et al., 2014b). Some of the literature on water in the Western United States has been skeptical of the real world application and influence of PA due to various higher level policies (Benson, 1998; Benson 2012; Tarlock, 2000; Tarlock, 2001). However, in this case, the RGC does not appear to change the influence of water right priority on average.

It is possible but unlikely that the strong and reliable influence of water right priority is being misconstrued. This is because priority ranking is essentially a question of who got to the SLV first. Farmers on ditches with senior water rights may have a generation or two advantage in local knowledge and capital accumulation and therefore could simply be more effective farmers. However, farming methods have changed dramatically since the $1850 \mathrm{~s}$, and due to turnover on ditch systems, new farmers may not absorb or inherit the local knowledge and capital of previous generations of farmers. It could also be argued that founders of the first ditch systems simply picked the best land. However, the best land would be more likely to increase crop production than duration of active diversion, amount of water diverted, and percentage of acres irrigated. In this analysis, water right priority has the strongest influence on variables related directly to water (months of active diversion, percent maximum volume diverted), as opposed to crops (percent acres irrigated). Thus, it is more likely that the signal is related to water right priority itself and not the quality of the land for farming or the quality of the farmers. Overall, this analysis adds to the growing body of evidence that property rights are influential when they are enforced (Meinzen-Dick, 2014; Torpey-Saboe, et al., 2015; Xu et al., 2014a, 2014b) and that higher levels of policy can matter for the real-world implementation of property rights (Ostrom, 2005).

\subsection{Hypotheses 2, 3, and 4: Geography} Catchment Area

As expected (Lam 1998; USDA, 2012), increasing catchment area improves irrigation performance. Systems with the largest catchment areas are more likely to have physical access to larger volumes of water throughout the year. As illustrated by the regressions on data subset by 
SWE, because larger catchments have larger flow volumes, this positive effect becomes even more important during drought when flow volumes are limited. During dry and very dry years, for percent maximum volume diverted, catchment area is significantly $(\mathrm{p}<0.05)$ more influential than water right priority rank (Table 7 in the supplementary material).

It is unlikely this result is being misconstrued. Larger catchment areas should be found on systems farther downstream with more diversions upstream of them, yet the influence of catchment area is positive while the influence of upstream ranking is negative. That these influences are in opposite directions and that these influences are in their expected directions gives credibility to the straightforward interpretation advanced here. And while tributaries are likely to have smaller catchment areas and thus confound these results, by including tributary diversion and elevation in the regressions, it is unlikely that the results are being biased.

\section{Tributary Diversion}

Although this result is not statistically significant for months of active diversion, the result is as expected (Lam 1998; Xu et al., 2014b): diverting from a tributary harms irrigation performance, particularly irrigated acreage. With fewer streams feeding a diversion on a tributary, there are fewer independent sources of supply to rely on, increasing the variability of water supply. This effect is strongest for percent acres irrigated and during drought (Table 6 in the supplementary material). This implies that without a diversity of catchments in shortage, each melting off snow at different times and rates, irrigation systems cannot on average divert enough water to reliably irrigate their land despite diverting water for an equivalent number of months as those on mainstems. It may be that irrigators, as individuals, understand that the runoff from a given catchment is somewhat unpredictable, as the hydrograph depends on seasonal factors such as snow depth and density, dust accumulation on the snow, wind direction and speed, tree cover, cloud cover, local temperature variations, and soil saturation, among other influences. Not wanting to lose a crop, this high variability prompts them to plant acreage conservatively, and results in lower irrigated acreage individually - and when summed, collectively - on tributaries. It is also true that in the SLV irrigation systems on tributaries are more likely to be used by ranchers growing native meadow hay, and therefore these systems have higher variability in irrigated area due to crop choice, leading to lower than average percent area irrigated during droughts.

\section{Upstream Rank}

The fourth hypothesis is not strongly supported. Only for percent maximum volume diverted is the coefficient significant $(\mathrm{p}<0.05)$ and the effect size is relatively small, though it is in the expected direction (-0.15). Without any of the other factors in place, this would be surprising (Janssen et al., 2011; Lam 1998), especially considering the local aphorism that it is "better to be upstream with a shovel than downstream with a water right." However, because of the strong influence of water rights, geographic features like catchment area and tributary diversion, and surface reservoirs in drought, the lack of strong support for this hypothesis is perhaps unsurprising. It appears that, overall, water rights are more influential in the SLV than the number of users upstream. That said, overall, it is better to be upstream than downstream, given that in all regressions performed - including on data subset by climatic conditions - the coefficient on upstream ranking is negative and significant for percent maximum volume diverted, an important outcome for irrigation systems. 


\subsection{Hypothesis 5: Water Rights in Context Weather}

Figure 3 illustrates that the marginal effect of water right priority rank has an inverted U shaped curve, where water rights have lower or no influence on average for systems that experience high and low levels of snowpack. Consider that for senior right holders, water right priority rank does not explain much of the variation in the outcome variables, because seniors are essentially not restricted in their ability to access water except in very dry years. Therefore, junior irrigators deserve more attention. One explanation for this inverted $U$ shaped curve is that when there is ample water available as snowmelt, the restrictive nature of PA does not take effect - fewer junior irrigators are curtailed because more seniors are satisfied, and therefore water rights have less influence. At very low levels of snowpack, the physical rather than legal availability of water is a limiting factor and even some seniors are cut short. Only at moderate levels of snowpack, when sufficient snow is available for most users to get at least some water, does the lifting of the limits imposed by PA on junior irrigators make a difference for outcomes.

\section{Cultural Norms}

The results do not support the hypothesis that cultural norms have a moderating effect on the influence of water right priority rank on the outcomes measured. These results undermine Kamran \& Shivakoti (2013), who found that a water management regime which did not conflict with local norms and evolved in the community rather than being imposed by a colonial power was more stable. That said, in support of Kamran \& Shivakoti (2013), one explanation for the strong influence of PA overall is that it was codified based on local norms of Anglo irrigators in the late 1800s. Absolute respect for private property rights is an important cultural factor in the United States, especially around water (Goldstein \& Hudak; 2017). It is possible that there are in fact moderating effects of being an acequia that this study is not equipped to detect. The measure of acequia status does not take into account the present-day ditch-level rules, but instead assumes a more culturally engrained set of norms that may have faded to the point that this study cannot detect them. Furthermore, the outcome measures used here would be best equipped to detect whether the repartamiento was still in place, the norm most in conflict with PA. Based on conversations with irrigators, there has been a coevolution of the historical common property regime of Hispanic irrigators and the private property regime imposed by PA on systems what were undoubtedly founded as acequias (Tang \& Gavin, 2015). This coevolution has likely resulted in a muting of the influence of traditional acequia norms, especially the repartamiento.

\section{Geography}

For percent maximum volume diverted, there are clear signs that at the extremes of catchment area and upstream ranking these variables become more powerful influences on outcomes and reduce the influence of water right priority rank (Figures 11 and 12 in the supplementary material). Percent area irrigated and percent maximum diversion, being far downstream and having a very large catchment area reduce the influence of water right priority rank to zero. The logic for this is the same as the logic used to explain the inverted U shaped curve observed for marginal effect of water right priority when moderated by SWE: an irrigation system that is limited or enabled by some other factor will be less influenced by water right priority rank than would otherwise be the case. As for tributaries, it is clear that, similar to SWE, when water 
supplies are strongly physically limiting, as they more frequently are on tributaries, water right priority rank has lower levels of influence.

Higher Level Policy

Despite the lack of evidence for the influence of higher level policy such as the RGC arising from interactions, it is possible that the RGC's influence is more subtle. Interestingly, Water District 26 - Saguache Creek - shows a significantly $(\mathrm{p}<0.05)$ stronger influence of water right priority than other Water Districts for all outcomes. This may be due to numerous factors, but four stand out. First, WD26 is not administered for the Rio Grande Compact, and so no rights holders are curtailed to satisfy deliver requirements, leaving their influence unmuted. Second, interactions between water right priority and tributary diversion show that on tributaries, water rights are less influential, and WD26 has fewer tributary diversions than most other Water Districts, increasing the influence of water right priority in WD26. Third, WD26 does not have any surface reservoirs, which are significantly associated with irrigation performance; a lack of surface storage would logically be expected then to increase the importance of other factors, including water right priority. Finally, WD26 has no acequias, and while this did not show up as a significant factor in determining the influence of PA, it is still plausible that a lack of acequias increases the importance of water right priority within a watershed. Combined, these factors could help explain why WD26 shows a more significant influence of water right priority rank than other Water Districts. There could be other unobserved factors at play (such as more stringent monitoring), but the conclusion is straightforward: water right priority matters most in this district, and this district is the most comparable district without RGC administration to the districts under RGC administration.

\section{Conclusion}

So, is it better to be upstream with a shovel or downstream with a water right? It appears it is better to be downstream with a senior water right, to a point. An irrigation system would have to be very far upstream to overcome the negative influence of being even a moderately junior irrigator. In the SLV at least, water right priority rank is the more consistently and more strongly beneficial than any other variable evaluated with the exception of catchment area, which has a comparable influence. And water rights have more say than geographic factors such as upstream rank and tributary diversion, despite their influence being significantly moderated by geography and climate. There are several policy implications of this research. However, in extreme drought, access to a surface reservoir is in the same range of importance as water right priority ranking (Table 5 in the supplemental material). The findings have implications for the effects of property rights in natural resources and add to the value of understanding institutions in context for irrigation in an era of climate change (Castex, et al., 2015; Hurlbert \& Mussetta, 2016), especially given that the influence of water right priority rank was highly sensitive to climatic conditions. Policy makers can use this research to better understand the interaction between water rights, geography, higher level institutions, and cultural norms. Indeed, the different influence of different factors on different outcomes illustrates the importance of careful, locally specific management strategies, even within the same river basin (Alcon, et al., 2014). Additionally, the variable influence of water rights in this study depending on context should lend credence to the idea that enforced water rights are not a panacea that will improve all outcomes in all contexts (Meinzen-Dick, 2007). It is likely that these findings are generalizable 
to snowmelt driven irrigation systems where water rights are strongly enforced (Torpey-Saboe, et al., 2015; Xu et al., 2014a, 2014b), given the diverse array of irrigation systems sampled and the ability to test inferences using the separate Water Districts within the SLV.

An important caveat is that water rights regimes other than PA may have different outcomes, especially proportional systems that are less sensitive to the amount of water available, such as the repartamiento historically practiced by acequias. Another important point is that these findings apply to de facto water rights, and that in this study de facto water rights and de jure water rights are the same. More work should be done to assess the relative importance of de facto and de jure water rights in situations where they differ, and how proportional rights regimes may differ from priority systems or permit-based, market-oriented approaches. Further questions also persist regarding climate change. More work needs to be done to assess how water rights perform under prolonged drought and what other tools might be needed to ensure resilience under persistently increasing aridity. Finally, on a methodological level, this study demonstrates the benefits of investments in public data and making that data widely available.

\section{References}

1. Agrawal, A. 2013. Studying the commons, governing common-pool resource outcomes: Some concluding thoughts. Environmental Science and Policy, 36: 86-91.

2. Alcon, F., Tapsuwan, S., Brouwer, R., \& de Miguel, M. D. (2014). Adoption of irrigation water policies to guarantee water supply: A choice experiment. Environmental Science and Policy, 44, 226-236.

3. Benson, R. 1998. Maintaining the Status Quo: Protecting Established Water Uses in the Pacific Northwest Despite the Rules of Prior Appropriation. Environmental Law, 28(1): 882-918.

4. Benson, R. 2012. Alive but Irrelevant: The Prior Appropriation Doctrine in Today's Western Water Law. University of Colorado Law Review, 83(3): 676-714.

5. Castex, V., Tejeda, E. M., \& Beniston, M. (2015). Water availability, use and governance in the wine producing region of Mendoza, Argentina. Environmental Science and Policy, 48, 1-8. http://doi.org/10.1016/j.envsci.2014.12.008

6. Cody, K., Smith, S., Cox, M., Andersson, K. 2015. Emergence of Collective Action in a Groundwater Commons: Irrigators in the San Luis Valley of Colorado. Society and Natural Resources, 28(4): 405-422.

7. Cox, M., and J. Ross. 2011. Robustness and vulnerability of community irrigation systems: The case of the Taos Valley Acequias. J. Environ. Econ. Manage. 61(3): 254266.

8. Cox, M. 2014. Modern disturbances to a long-lasting community-based resource management system: The Taos Valley Acequias. Global Environ. Change 24: 213-222.

9. Colorado Division of Water Resources. N.d. Division 3 (Alamosa): Rio Grande River Basin. Accessed Nov 5, 2016: http://water.state.co.us/DivisionsOffices/Div3RioGrandeRiverBasin/Pages/Div3RioGran deRB.aspx

10. Diamond \& Sekhon. 2013. Genetic Matching for Estimating Causal Effects: A General Multivariate Matching Method for Achieving Balance in Observational Studies. The Review of Economics and Statistics. 95(3): 932-945. 
11. Deryng, D., Elliott, J., Folberth, C., Muller, C., Pugh, T. A. M., Boote, K. J., ... Rosenzweig, C. (2016). Regional disparities in the beneficial effects of rising CO2 concentrations on crop water productivity. Nature Clim. Change, 6(8), 786-790.

12. Food and Agriculture Organization of the United Nations (FAO). 2012. Food insecurity in the world. Accessed Aug 25, 2016: http://www.fao.org/docrep/016/i3027e/i3027e.pdf

13. Fernald, A., Tidwell, V., Rivera, J., Rodríguez, S., Guldan, S., Steele, C., ... Cibils, A. 2012. Modeling Sustainability of Water, Environment, Livelihood, and Culture in Traditional Irrigation Communities and Their Linked Watersheds. Sustainability, 4(12): 2998-3022.

14. Gleick, P. 2003. Global freshwater resources: Soft-path solutions for the 21st century. Science, 302(5650): 1524-1528.

15. Goldstein, B. D., \& Hudak, J. M. (2017). Comparison of the role of property rights in right wing and left wing American and European environmental policy deliberations. Environmental Science \& Policy, 68, 28-34.

16. Grafton, R., Libecap, G., McGlennon, S., Landry, C., \& O’Brien, B. 2011. An Integrated Assessment of Water Markets: A Cross-Country Comparison. Review of Environmental Economics and Policy, 5(2): 219-239.

17. Gujarati, D. \& Porter, D. 2009. Basic Econometrics. New York, NY: McGraw-Hill.

18. Gupta, J. \& Lebel, L. 2010. Access and allocation in earth system governance: water and climate change compared. International Environmental Agreements, 10: 377-395.

19. Hansen, Z., Libecap, G., \& Lowe, S. 2011. Prior Climate Variability and Water Infrastructure: Historical Experience in the Western United States. In Libecap, G., \& Steckel, R. (Eds.), The Economics of Climate Change: Adaptations Past and Present: pp. 253-280. Chicago, IL: University of Chicago Press.

20. Ho, D. Imai, K., King, G., \& Stuart, E. 2007. Matching as Nonparametric Preprocessing for Reducing Model Dependence in Parametric Causal Inference. Political Analysis, 15: 199-236.

21. Hurlbert, M., \& Mussetta, P. (2016). Creating resilient water governance for irrigated producers in Mendoza, Argentina. Environmental Science and Policy, 58, 83-94.

22. Janssen, M. a., Anderies, J. M., \& Cardenas, J. C. 2011. Head-enders as stationary bandits in asymmetric commons: Comparing irrigation experiments in the laboratory and the field. Ecological Economics, 70(9): 1590-1598.

23. Janssen, M. A., \& Anderies, J. M. 2013. A multi-method approach to study robustness of social-ecological systems: the case of small-scale irrigation systems. Journal of Institutional Economics, 9(04): 427-447.

24. Kadirbeyoglu, Z., \& Ozertan, G. 2015. Power in the Governance of Common-Pool Resources: A comparative analysis of irrigation management decentralization in Turkey. Environmental Policy and Governance, 25: 157-171.

25. Kamran, M. A., \& Shivakoti, G. P. 2013. Comparative institutional analysis of customary rights and colonial law in spate irrigation systems of Pakistani Punjab. Water International, 38(5): 601-619.

26. Kenney, D. 2005. Prior Appropriation and Water Rights Reform in the Western United States. In Bruns, B., Ringler, C., Meinzen-Dick, R (Eds.), Water Rights Reform: Lessons for Institutional Design: pp. 167-182. Washington, D.C.: International Food Policy Research Institute.

27. Lam, W.F. 1998. Governing Irrigation Systems in Nepal: Institutions, Infrastructure, and 
Collective Action. Oakland, CA: Institute for Contemporary Studies.

28. Libecap, G. D. 2011. Institutional path dependence in climate adaptation: Coman's Some unsettled problems of irrigation. American Econonomic Review. 10(1): 1-19.

29. Lukas, J., Barsugli, J., Doesken, J., Rangwala, I., Wolter, K. 2014. Climate Change in Colorado: A Synthesis to Support Water Resources Management and Adaptation. A report for the Colorado Water Conservation Board by Western Water Assessment. Boulder, CO.

30. Mabry, J. 1996. Canals and Communities. Tucson, AZ: The University of Arizona Press.

31. Meinzen-Dick, R. 2007. Beyond panaceas in water institutions. Proceedings of the National Academy of Sciences, 104(39): 15200-15205.

32. Meinzen-Dick, R. 2014. Property rights and sustainable irrigation: A developing country perspective. Agricultural Water Management, 145: 23-31.

33. Mix, K., V. Lopes, and W. Rast. 2011. Annual and growing season temperature changes in the San Luis Valley, Colorado. Water Air Soil Pollut. 220(1): 189-203.

34. Mix, K., Lopes, V. L., \& Rast, W. 2012. Growing season expansion and related changes in monthly temperature and growing degree days in the Inter-Montane Desert of the San Luis Valley, Colorado. Climatic Change, 114(3-4): 723-744.

35. Mukhtarov, F., Fox, S., Mukhamedova, N., \& Wegerich, K. (2015). Interactive institutional design and contextual relevance: Water user groups in Turkey, Azerbaijan and Uzbekistan. Environmental Science and Policy, 53, 206-214.

36. Ostrom, E. 1992. Crafting Institutions for User-governing Irrigation Systems. San Francisco, CA: Institute of Contemporary Studies.

37. Ostrom E. 2005. Understanding Institutional Diversity. Princeton, NJ: Princeton University Press.

38. Paddock, W. 2013. Introduction to Water Resource Issues in Water Division No. 3, The Rio Grande Basin. Prepared for: The Colorado Law Acequia Assistance Project. March, 2013.

39. Poteete, A. R., M. A. Janssen, and E. Ostrom. 2010. Working together: Collective action, the commons, and multiple methods in practice. Princeton, NJ: Princeton University Press.

40. Rivera, J. 1998. Acequia Culture: Water, Land, and Community in the Southwest. Albuquerque, NM: University of New Mexico Press.

41. Rodriguez, S. 2006. Acequia: Water Sharing, Sanctity, and Place. Santa Fe, NM: School for Advanced Research Press.

42. Sabatier, P. 2007. Theories of the Policy Process, Second Edition. Cambridge, MA: Westview Press.

43. Smith, Steven M. 2016. Common Property Resources and New Entrants: Uncovering the Bias and Effects of New Users. Journal of the Association of Environmental and Resource Economists 3(1): 1-36.

44. Tang, R., \& Gavin, M. C. (2015). Degradation and re-emergence of the commons: The impacts of government policies on traditional resource management institutions in China. Environmental Science and Policy, 52, 89-98.

45. Tarlock, D. 2000. Prior Appropriation: Rule, Principle, or Rhetoric? North Dakota Law Review, 76: 881-910.

46. Tarlock, D. 2001. The Future of Prior Appropriation in the New West. Natural Resources Law Journal, 41: 769-793. 
47. Thiros, S.A., Bexfield, L.M., Anning, D.W., and Huntington, J.M., eds. 2010. Conceptual understanding and groundwater quality of selected basin-fill aquifers in the Southwestern United States: U.S. Geological Professional Paper 1781, 288 p.

48. Torpey-Saboe, N., Andersson, K.P., Mwangi, E., Persha, L., Salk, C., \& Wright, G.D. 2015. Benefit Sharing Among Local Resource Users: The Role of Property Rights. World Development, 72(1): 408-418.

49. United Nations International Fund for Agriculture Development (UN IFAD). N.D. Water Facts and Figures. Accessed on August 25, 2016: https://www.ifad.org/topic/facts_figures/overview

50. United States Department of Agriculture (USDA). 2012. Part 630 Hydrology National Engineering Handbook Chapter 14 Stage Discharge Relations. Accessed on August 25, 2016: http://www.nrcs.usda.gov/wps/portal/nrcs/detailfull//?cid=stelprdb1043063

51. United States Department of Agriculture (USDA). 2014. Quick Stats. National Agricultural Statistics Service. Accessed on May 21, 2017: https://quickstats.nass.usda.gov/?source_desc $=$ CENSUS

52. Vicuña, S., McPhee, J., \& Garreaud, R. D. 2012. Agriculture Vulnerability to Climate Change in a Snowmelt-Driven Basin in Semiarid Chile. Journal of Water Resources Planning and Management, 138(5): 431-441.

53. Villamayor-Tomas, 2012. Robustness to droughts in a multi-level governance irrigation systems: A statistical analysis of Riegos del Alto Aragon irrigation systems. Prepared for: Design and Dynamics of Institutions for Collective Action. Nov. 29-Dec. 1, 2012. Utretch.

54. Wheeler, T. \& von Braun, J. 2013. Climate Change Impacts on Global Food Security. Science, 341(6145): 508-513.

55. Wilson, D., Ostrom, E., \& Cox, M. 2013. Generalizing the core design principles for the efficacy of groups. Journal of Economic Behavior \& Organization, 90: S21-S32.

56. Woodhouse, C.A., D.W. Stahle, and J. Villanueva-Díaz. 2012. Rio Grande and Rio Conchos water supply variability from instrumental and paleoclimatic records. Climate Research, 51: 125-136.

57. Xu, W., Lowe, S., \& Adams, R. 2014a. Climate change, water rights, and water supply: The case of irrigated agriculture in Idaho. Water Resources Research, 50: 9675-9695.

58. Xu, W., Lowe, S., \& Zhang, S. 2014b. An analysis of irrigated agricultural outcomes under the prior appropriation doctrine: hypotheses and applications. Applied Economics, 46(22): 2639-2652.

59. Zeileis, A. 2004. Econometric Computing with HC and HAC Covariance Matrix Estimators. Journal of Statistical Software, 11(10), 1-17.

60. Zwart, W., \& Leclert, L. 2010. A remote sensing-based irrigation performance assessment: a case study of the Office du Niger in Mali. Irrigation Science, 28(5): 371385 . 